\title{
Attribution of the river flow growth in the Plata Basin
}

\author{
Moira E. Doyle ${ }^{\mathrm{a}, \mathrm{b} *}$ and Vicente R. Barros ${ }^{\mathrm{a}, \mathrm{b}}$ \\ a Centro de Investigaciones del Mar y la Atmósfera (CIMA/CONICET-UBA) Buenos Aires, Argentina \\ b Departamento de Ciencias de la Atmósfera y los Océanos. FCEN. Universidad de Buenos Aires. Buenos Aires, Argentina
}

\begin{abstract}
A regression approach was used to quantitatively estimate the attribution of the notable growth in the river flows of the Plata Basin during 1960-1999. The study was conducted in seven large basins that account for most of the Plata River discharge. Annual rainfall integrated over each basin and annual river flows at their closing points were used for the analysis. The contribution of rainfall changes during each of the three phases of El Niño-Southern Oscillation to total rainfall change in these basins was also calculated.

The two main drivers for the generalized growth of the river flows were the increased precipitation and the decreased evaporation attributable to land use change, including deforestation of natural forest and crop switch from sugarcane and coffee trees to soybean. Other evaporation changes played a minor role. There was a north-south gradient in the respective importance of each driver, with land use change having greater weight in the northern basins and the precipitation increase in the southern ones. Thus, in the northern part of the Upper Paraná Basin, despite the negative trend in precipitation there was a strong augment of the river flow caused by land use change. The contribution to the positive trend of the stream flows in the middle of the Plata Basin came from both land use change and increased precipitation. Finally, in the south, the Uruguay River flow change was basically due to the precipitation trend that was not only observed during the El Niño phase, but also during the Neutral phase.

Only in the Middle Paraguay Basin was the shift to more frequent and intense El Niño events that took place in the 1970s an important factor in the contribution of precipitation to streamflow trends. Copyright (C) 2010 Royal Meteorological Society
\end{abstract}

KEY WORDS Plata Basin; trends; land use change; precipitation; river flow

Received 2 February 2010; Revised 19 August 2010; Accepted 21 August 2010

\section{Introduction}

The Plata Basin, stretching over 3.2 million $\mathrm{km}^{2}$, is the fifth largest basin of the world (Figure 1); its two main tributaries are the Paraná River with a huge basin of 2.6 million $\mathrm{km}^{2}$, including 1 million $\mathrm{km}^{2}$ from the Paraguay Basin, and the Uruguay River. Located at the heart of the most developed region of South America, the Plata Basin has abundant water resources, used to produce most of the regional electricity and to sustain agriculture. Harvests and livestock supply most of the food for the countries in the region, and also generate their main export income. Water resources in the Plata Basin are therefore crucial for the sustainable development of the region and in a context of climate change justify growing attention.

During the first half of the 20th century, the flow of the Paraná, Paraguay and Uruguay Rivers had a tendency to decrease. This behaviour was reversed during the second half, especially since the 1970s when an important positive change was observed (García and Vargas, 1997;

\footnotetext{
* Correspondence to: Moira E. Doyle, Dto. Cs. De la Atmósfera y los Océanos, Ciudad Universitaria, Pabellón II, 2do piso, 1428 Buenos Aires, Argentina. E-mail: doyle@cima.fcen.uba.ar
}

Genta et al., 1998; Krüger et al., 1998). The mean discharge to the Plata Basin as a whole increased 35\% from 1951-1970 to 1980-1999 (Berbery and Barros, 2002), improving power generation, navigation and other uses of water resources. However, there were also some negative impacts because large floods became more frequent. Should these high mean flows remain or not in the near future is an important issue because the return to the early 1960s mean flows would have important negative consequences. Therefore, understanding the cause of such a remarkable change, apart from its academic value, is of important practical interest.

One possible driver of this change could be land use change. During the past century, agriculture has expanded through deforestation of the Atlantic Forest, an ecosystem that stretched along the entire southern coast of Brazil and extended into a great part of the Paraná and Paraguay Basins. According to Tucci (2003), forest-like cover in the states of Sao Paulo and Paraná, situated in the middle of the Paraná Basin, decreased from approximately $70 \%$ in 1907 to less than $8 \%$ in 1990. In these states, there were additional land use changes starting at the end of the 1960s, mainly the substitution of sugarcane and coffee trees for soybean. Deforestation took place, as well, in eastern Paraguay where natural forest cover declined from $45 \%$ in 1960 to $15 \%$ in 1990 with an accelerated 


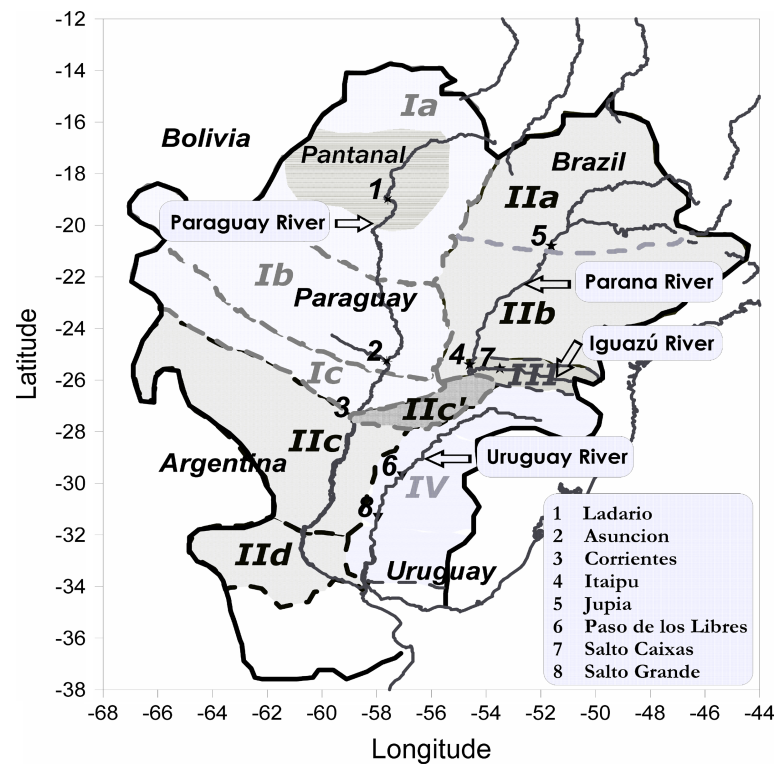

Figure 1. The Plata Basin, main rivers, hydrological stations and sub-basins: (Ia) upper, (Ib) middle and (Ic) lower Paraguay; (IIa) northern upper, (IIb) southern upper, (IIc) middle, $\left(I I c^{\prime}\right)$ northern middle and (IId) lower Paraná; (III) Iguazú; (IV) Uruguay. Gauging stations: (1) Ladario, (2) Asunción, (3) Corrientes, (4) Itaipú, (5) Jupiá, (6) Paso de los Libres, (7) Salto Caxias and (8) Salto Grande. This figure is available in colour online at wileyonlinelibrary.com/journal/joc

rate at the end of the century (Coronel et al., 2006). The cerrado, a savanna type that covered approximately half of the northern part of the Paraná Basin in 1960, was gradually converted to annual crops (sugarcane and soybean) and by 2000 , only a small percentage in patchy areas had survived (Volpi, 2008). Since deforestation usually leads to increased flow in rivers as a result of increased runoff (Sahin and Hall, 1996), at least part of the river flow increase since 1970 should be expected to be the consequence of deforestation.

In most of the Plata Basin, the increase of streamflows was observed in rainfall data as well. There were positive trends in precipitation over most of the subtropical South America, east of the Andes, including the middle and south of the Plata Basin during the 1960-1990 period with a steep increment in the 1970s (Castañeda and Barros, 1994; Barros et al., 2000, 2008). However, in the northern and central part of the Plata Basin, the mean of the 1980-1999 spatial-averaged precipitation increased with respect to $1951-1970$ merely $16 \%$ compared with a discharge growth of 35\% (Berbery and Barros, 2002). This different percent increment is not by itself proof of river-flow trends being caused by deforestation or any other process reducing evaporation. Indeed, the analysis of interannual and longer time variability of the components of the hydrological cycle in the Plata Basin reveals an amplified percent response of discharges to changes in precipitation (Berbery and Barros, 2002; Tucci, 2003).

Both positive precipitation trends and land use change have likely contributed to the growth of the river flows of the Plata Basin since the 1970s. However, it is not clear how much each of these two processes and a possible evaporation trend caused by climatic factors have contributed to the discharge changes of the Plata River. Hence, the purpose of this article is to quantitatively estimate the main drivers that have contributed to the increase of river discharge in the Plata Basin during the second half of the 20th century.

Nowadays, especially since the 1980 s, there is a good coverage of rainfall and hydrological observations over most of the Plata Basin. However, there are only a few records in the northern sector of the Plata Basin starting in the 1960s or earlier. The lack of long climate and hydrological records in the catchments of the Paraná and Paraguay Rivers hinders the study of the causes of the strong streamflow trend that took place during the last four decades of the 20th century. Even worse is the case of other meteorological long-term records, such as temperature, humidity, wind and radiation, that are frequently used for evaporation estimates, and of which a great part of the basin was practically void. This data constraint limits the applicability of modelling tools to the study of long-term evaporation and other hydrological trends as a function of climate variability and land use change, unless they are accompanied with some speculative assumptions. As an alternative approach, this study makes use of the few data available to construct statistical relationships consistent with longterm hydrological balances to infer from them the main driver contributions to the observed river flow changes.

The relative contribution of land use change and precipitation trends is not the only aspect of the growth of the Plata Basin river flows not yet understood. Another issue is the climate forcing of the precipitation trends that eventually contributed to the changes in the river flows. In most of the Plata Basin, and especially in its middle sector, there is a clear signal of the El Niño-Southern oscillation (ENSO) with more (less) than average precipitation in El Niño (La Niña) phase (Ropelewski and Halpert, 1987; Aceituno, 1988; Rao and Hada, 1990). The positive (negative) Pacific decadal oscillation (PDO) phase, related to high (low) El Niño activity (Mantua et al., 1997; Zhang et al., 1997) started its last positive phase in the 1970s and lasted, at least, until the end of the century. Hence, the PDO phase could be a factor favouring precipitation in the region. In fact, Haylock et al. (2006) found that the change to a generally more negative Southern Oscillation Index (SOI) was associated with rainfall trends in a larger region including the Plata Basin. Therefore, it is likely that the change in the PDO phase could have also contributed to the streamflow growth since the 1970s.

The article is structured in seven sections: data is described in Section 2; hydro-climatological aspects of the Plata Basin are addressed in Section 3. As a background, Section 4 revisits the issue of rainfall and discharge trends. The attribution of the discharge trends is discussed in Section 5. Section 6 addresses the issue of how much of the rainfall changes in the main basins of 
the Plata are attributable to changes in the ENSO phases. Concluding remarks are presented in Section 7.

\section{Data}

There are few locations with long enough discharge measurements to address the problem of trends or interdecadal changes. Although this is a severe restriction to conduct a geographically more detailed study, a few stations at the closing points of the large basins were available (Table I).

The three most important sub-basins of the Plata Basin, both in terms of their catchment area and runoff are the Paraná, Paraguay and Uruguay (Figure 1). The upper Paraguay River, basin $I a$ in Figure 1, extends from its catchments to the border between Paraguay and Brazil, and includes the world's largest wetland, the Pantanal. The lag between flood peaks in the south and the north of the Pantanal is about 4 months and this has a major influence on the flow regime of the Paraguay River. The middle Paraguay River (basin $I b$ ) stretches inside Paraguay to its confluence with the Pilcomayo at Asunción. The lower Paraguay River flows from this point until its outlet into the Paraná River at Corrientes (basin Ic). Two gauging stations were selected in the Paraguay River: Ladario at the outlet of the Pantanal in the upper Paraguay and Asunción. Ladario flows were calculated from the river levels with a rating curve based on measurements taken in 1996 for the study of the navigation system of the Paraguay and Paraná Rivers (Hidroservice-Louis Berger-EIH, 1996). Asunción discharges were available from the hydraulic laboratory of the National Administration of Navigation and Ports of Paraguay.

The Upper Paraná River (basin $I I a$ and $I I b$ ) extends from its catchments to the confluence with one of its main tributaries, the Iguazú River. It has two longterm series of discharges available: at Jupiá, closing point for the northern part of the basin (IIa), and at Itaipú immediately before the juncture with the Iguazú River. The Salto Caxias gauging station is near the outlet of the Iguazú River (basin III) on the Paraná. Natural discharges of these Brazilian gauging stations were obtained from the Operador Nacional do Sistema Elétrico (ONS). The middle Paraná (basin IIc), which lies between the meeting with Iguazú River and the city

Table I. Streamflow stations.

\begin{tabular}{llll}
\hline Station & Latitude & Longitude & River \\
\hline Ladario & $19^{\circ} 00^{\prime} \mathrm{S}$ & $57^{\circ} 35^{\prime} \mathrm{W}$ & Paraguay \\
Asunción & $25^{\circ} 16^{\prime} \mathrm{S}$ & $57^{\circ} 38^{\prime} \mathrm{W}$ & Paraguay \\
Corrientes & $27^{\circ} 27^{\prime} \mathrm{S}$ & $58^{\circ} 49^{\prime} \mathrm{W}$ & Paraná \\
Itaipú & $25^{\circ} 24^{\prime} \mathrm{S}$ & $54^{\circ} 36^{\prime} \mathrm{W}$ & Paraná \\
Jupia & $20^{\circ} 48^{\prime} \mathrm{S}$ & $51^{\circ} 37^{\prime} \mathrm{W}$ & Paraná \\
Salto Caxias & $25^{\circ} 33^{\prime} \mathrm{S}$ & $53^{\circ} 30^{\prime} \mathrm{W}$ & Iguazú \\
Salto Grande & $31^{\circ} 19^{\prime} \mathrm{S}$ & $57^{\circ} 57^{\prime} \mathrm{W}$ & Uruguay \\
\hline
\end{tabular}

of Santa Fe (Argentina), has a broad, complex floodplain extending $600 \mathrm{~km}$ that receives the discharge of its main tributary, the Paraguay River. Immediately downstream of the confluence of the Paraná and Paraguay Rivers is the gauging station of Corrientes, Argentina. Data for this station, provided by the Argentine Water Resource Secretary, were used to analyse the northern sector of this basin $\left(I I c^{\prime}\right)$. For the sake of simplicity, hereafter this northern sector of the river and of the basin will be referred to as Middle Paraná River and Middle Paraná Basin, respectively. Downstream of Corrientes, gauging stations are either unable to represent the discharge because the river diverges in various branches not gauged or do not have long enough records. This sector of the Paraná River does not receive important runoffs and is not discussed in this article. The Lower Paraná (IId) flows in a gentle sloping plain and meets with the Uruguay River to form the Plata River.

The Uruguay River originates in southern Brazil near the Atlantic coast and together with the Paraná River contributes to the bulk of the Plata River streamflow (basin $I V$ ). For the Uruguay River, only two series with long records were available. Discharges measured at Salto Grande were selected for this study because the other available series was at Paso de los Libres, only $150 \mathrm{~km}$ upstream. Salto Grande time series is available from the Argentine Water Resource Secretary http://www.mecon.gov.ar/hidricos/mapashidricos/ mapageneral.htm

Total monthly precipitations for the 1960-1999 period were obtained from the Argentine National Meteorological Service, the Brazilian National Water Agency (ANA) and the Global Historical Climatology Network (GHCN) (Vose et al., 1992). Only monthly series with less than $10 \%$ missing data that successfully tested for homogeneity were included in the analysis. They are distributed as follows: 33 in Argentina, 10 in Uruguay, 12 in Paraguay and 24 in Brazil, all of them within the Plata Basin. Monthly data were then interpolated to a $3^{\circ} \times 3^{\circ}$ grid using the Kriging method (Cressie, 1991). Given that there are very few long-term series available north of $22^{\circ} \mathrm{S}$ and west of $49^{\circ} \mathrm{W}$, this region was completed using the Willmott and Matsuura (2001) interpolated database. However, it is expected that part of their data in this region results from the application of interpolation/extrapolation schemes rather than from real data.

As most of the flows in the Upper Paraná and Paraguay Rivers reflect the annual rainfall regime, i.e. considerably more abundant precipitation during the warm months, yearly data both in streamflows and rainfall were computed from October to September.

Monthly gridded maximum and minimum surface temperature means over the Plata Basin were taken from the Climate Research Unit of the University of East Anglia, data UEA CRU TS2p1 http://iridl.ldeo.columbia.edu/ SOURCES/.UEA/.CRU/.TS2p1/.dataset_documentation. $\mathrm{html}$. They were used to calculate the areal monthly and 
Table II. Mean annual precipitation over basins and river flows and their difference in $\mathrm{m}^{3} / \mathrm{s}$. (1960-1999). The percentage with respect to precipitation is given in brackets. More details in the text.

\begin{tabular}{|c|c|c|c|c|}
\hline River & Station & Precipitation & Discharge & Difference \\
\hline \multirow[t]{3}{*}{ Paraguay } & Ladario & 10380 & $1360(13)$ & 9020 (87) \\
\hline & Asunción & - & 3320 & - \\
\hline & Asuncion-Ladario & 14300 & $2000(14)$ & $12300(86)$ \\
\hline \multirow[t]{5}{*}{ Paraná } & Jupiá & 19770 & $6710(34)$ & $13060(66)$ \\
\hline & Itaipú & - & 11090 & - \\
\hline & Itaipú-Jupia & 18040 & $4380(24)$ & $13660(76)$ \\
\hline & Corrientes & - & 18420 & - \\
\hline & Corrientes-Asunción-Itaipú-Salto Caxias & 8060 & $2570(32)$ & $5480(68)$ \\
\hline Iguazú & Salto Caxias & 3670 & $1440(40)$ & $2230(60)$ \\
\hline Uruguay & Salto Grande & 12650 & $5230(41)$ & $7420(59)$ \\
\hline
\end{tabular}

annual mean temperature, and the mean daily temperature range for each sub-basin. In addition, monthly mean temperature interpolated and documented by Matsuura and Willmott (2009), known as the Delaware University dataset, was used to cross check the UEA CRU temperature data. Both datasets rely on few stations, especially in the northwest of the Plata Basin and it is not clear if they were checked for urban growth and other sources of inhomogeneity. Correlations between Delaware and UEA CRU mean annual temperatures, on a sub-basin level, vary between 0.77 in the Pantanal to over 0.90 in the southern basins. This indicates consistency between both datasets, but at the same time reflects certain uncertainty.

Monthly mean sea-surface temperatures for region $\mathrm{El}$ Niño 3.4 were used to analyse the relationship between ENSO phases and precipitation. Months were classified as belonging to El Niño (La Niña) phase if the anomaly of a 5-month running mean was above (below) $0.4{ }^{\circ} \mathrm{C}$ $\left(-0.4^{\circ} \mathrm{C}\right)$ for a minimum period of 6 months, relative to the base period 1950-1979 (Trenberth, 1997). Months not included in any of these two events were classified as part of the Neutral phase.

\section{Hydro-climatological features of the Plata Basin}

In the north of the Plata Basin, rainfall has monsoon features, i.e. it is considerably more abundant during the warm part of the year (October-March). This regime is also observed in the west of the basin, namely in the west of Paraguay and in west and central Argentina. However, in the middle of the Plata Basin, where a great part of the streamflow of the principal rivers originates, rainfall is more evenly distributed throughout the year (Grimm et al., 2000). This fact, together with the delay in the Paraguay River flows with respect to the monsoon rainfall in the Pantanal region (Hamilton, 1999; Collischonn et al., 2001; Bertoni et al., 2003) and the small average slope of the terrain of less than $0.05 \mathrm{~m} / \mathrm{km}$ in the rest of the Paraguay Basin, contributes to modify the Paraná River regime from typically monsoonic in the north to one with a moderated annual cycle in the south.
Precipitations shown in Table II are averages over the basins corresponding to the closing point stations indicated in column 2 and depicted in Figure 1. Their values are presented in a nonconventional form, namely in $\mathrm{m}^{3} / \mathrm{s}$ to facilitate their comparison with river streamflows. Thus, the annual mean precipitation values for each basin was multiplied by the corresponding area extension and divided by the seconds in a year.

Precipitation $(P)$ over a basin in a given period is distributed as follows:

$$
P=R+E+I+S
$$

where $R$ stands for the runoff to the river including its superficial and sub-superficial components, $E$ for evaporation, $I$ for deep infiltration and $S$ for the storage or reduction of water in the different components of the basin such as soil, lakes, brooks and rivers and eventually dam lakes.

When averaging over several decades, the contribution to the main river streamflow is basically given by the basin runoff. Therefore, considering that deep infiltration is rather small and that for long-term averages the mean storage tends to be negligible, the annual average evaporation can be approximated by the difference between averaged precipitation and the contribution to the main river stream flow:

$$
E=P-R
$$

Despite the fact that there are many dams upstream from Itaipú affecting the Paraná River flow, their storage capacity is not enough to alter the long-term mean storage of the basin. However, the comparison between regulated and natural monthly flows in Itaipú indicates that the regulation upstream from this location, in general, transfers flows from summer to winter and spring. In addition, the long-term net water transfer from the warm to the cold semester can be important in most of the Plata Basin because of the monsoon rainfall regime and because great part of the Plata Basin has small slopes with slow superficial runoffs that cause net water transfers from the rainy to the drier semesters. These conditions 
hamper the use of the hydrological balance to infer longterm mean evaporation at seasonal scale and limit it to the annual scale.

To assess the contribution to streamflows of basins that are in the middle of a river course, differences between streamflows at the output and input of the basin were calculated. Since in this study these differences are taken over 20- to 40-year periods, the effect of the time lag between the flow at the input and output of the basins can be neglected.

As expected, according to the north-south temperature gradient, the share of precipitation used in evaporation is in general larger in the more tropical regions of the basin, than in the southern area, ranging from $87 \%$ in the Upper Paraguay and $66 \%$ in the northern Upper Paraná to 59\% in the Uruguay Basin (Table II). However, this is also in part due to the different slopes of the basins that control the runoff speed and consequently the time that water is exposed to evaporation. Slopes in the Paraguay Basin are considerably smaller than in the eastern part of the Plata Basin where, however, they are no greater than $0.3 \mathrm{~m} / \mathrm{km}$ (Coronel et al., 2006). This feature favours a slow water runoff and enhances the already high evaporation, resulting from the high temperatures of this subtropical region. Consequently, the evaporation/precipitation ratio is high over the whole basin with values ranging from 50 to almost $90 \%$. Hence, the precipitation fraction that runs off to the rivers is rather small, and the changes in evaporation may lead to important percent changes in the runoff. As evaporation is critically dependent on the vegetation cover, this feature of the Plata Basin makes land use change an important and potential factor that can alter river flows. Evidences of this impact are discussed in Section 5.

\section{Precipitation and river streamflow trends}

\subsection{Precipitation trends}

As mentioned earlier, there have been trends and changes in annual rainfall during the last decades of the past century over southeastern South America. In most of the southern part of the Plata Basin, i.e. in Argentina, Uruguay and southern Brazil, positive trends started during the 1960s and continued during the following four decades, while in the central stretch of the Plata Basin, there was a steep positive trend concentrated mostly during the 1970s (Barros et al., 2000, 2008). This was also documented for the states of Sao Paulo and Paraná in Brazil (Krüger et al., 1998) and for the Upper Paraguay (Collischonn et al., 2001), where there was an abrupt trend concentrated in a 10 -year period with a later decline.

In this article, these changes are illustrated in a more general form as trends over the four decades integrated in the Plata Basin, as a background for the discussion on the attribution of river streamflow trends. Figure 2 shows that there were positive changes in the annual precipitation in most of the Plata Basin in the 1960-1999 period, except

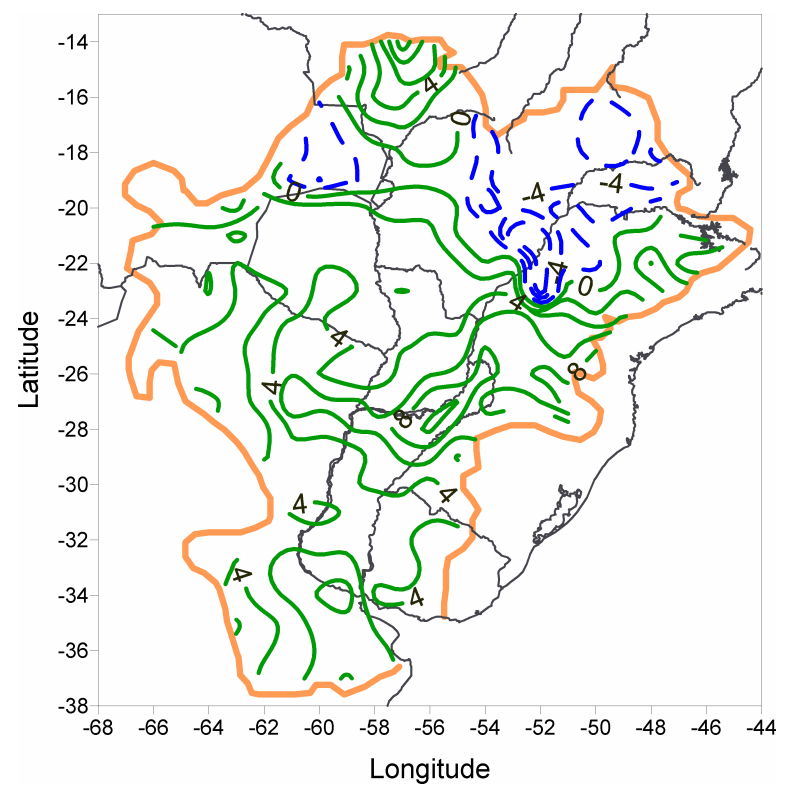

Figure 2. Annual rainfall linear trends in mm/year for the 1960-1999 period. This figure is available in colour online at wileyonlinelibrary. $\mathrm{com} /$ journal/joc

over the northeastern sector of the Upper Paraná Basin and in some parts of the Pantanal, where trends were negative. The most positive trends, over $8 \mathrm{~mm} / \mathrm{year}$, were in the middle Paraná Basin. Rainfall trends integrated over the basins, in $\mathrm{m}^{3} / \mathrm{s}$, are shown in Table III. They are a good description of the evolution of integrated rainfall over the basins with the exception of those calculated for the Pantanal and the northern Upper Paraná Basins, where there was a maximum in the early 1980s. However, trends in the Pantanal should be considered with caution since during the 1960s and 1970s, precipitation observations were scarce.

\subsection{River streamflow trends}

As in the case of rainfall, some mean annual streamflows presented rapid changes referred to, by some authors, as jumps. For instance, a study by Eletrobrás in 1995, quoted by Tucci (2003), discusses a jump in 1975 in the Upper Paraná flows, upstream of Itaipú. Actually, most of the Paraná and the Paraguay discharge records show trends concentrated over a short period of 10-15 years around the 1970s, while in the Uruguay River, consistent with precipitation changes, the trend extended over the four decades.

As a general overview of hydrological changes in the Plata Basin, like in the case of precipitation, Table III also presents discharge trends over the 40-year period. River flows between 1960 and 1999 have been increasing in the Paraná, Paraguay, Iguazú and Uruguay Rivers. All trends are statistically significant except in the Uruguay River, that nonetheless is strongly positive. The growth of the annual flow was such that, in all cases except Jupiá, by the end of the century, streamflows were near or above $40 \%$ of their initial value in 1960s. The Paraguay and 
Table III. Annual trends for the 1960-1999 period ( $\mathrm{m}^{3} / \mathrm{s} /$ year). Percentage of the trend integrated over the 40-year period with respect to the mean value is given in brackets.

\begin{tabular}{lccc}
\hline Basin (Station) & Precipitation & Discharge & Difference \\
\hline Pantanal (Ladario) & $12(5)$ & $23^{*}(62)$ & $-9(-4)$ \\
Paraguay (Asunción) & - & $61^{*}(73)$ & - \\
Middle Paraguay (Asunción-Ladario) & $33(9)$ & $41^{*}(82)$ & $-8(-3)$ \\
Northern Upper Paraná (Jupiá) & $-21(-4)$ & $28(17)$ & $-49(-15)$ \\
Upper Paraná (Itaipu) & - & $106^{*}(38)$ & - \\
Southern Upper Paraná (Itaipú-Jupia) & $43(10)$ & $78^{*}(66)$ & $-35(-10)$ \\
Middle Paraná (Corrientes) & - & $197^{*}(43)$ & - \\
Middle Paraná (Corrientes-Asunción-Itaipú-Salto Caxias) & $33(16)$ & $7(11)$ & $26(9)$ \\
Iguazú (Salto Caxias) & $18^{*}(20)$ & $24^{*}(66)$ & $-6(-13)$ \\
Uruguay (Salto Grande) & $52(16)$ & $45(34)$ & $7(4)$ \\
\hline
\end{tabular}

* Values significant at the $95 \%$ level.

Iguazú Rivers had the highest percent increments, $63 \%$ at Ladario, $74 \%$ at Asunción and $96 \%$ at Salto Caxias.

\section{Attribution of the streamflow trends}

Precipitation determines the runoff not only by its surplus over evaporation, storage and infiltration but also because these processes are dependent on precipitation in several ways. For instance, evaporation is a function of many variables but, when precipitation is below the potential evapotranspiration for long periods of time, it strongly varies with it. However, when the soil is sufficiently wet, water uptake is assumed to be equal to potential evapotranspiration, which is a function of temperature and other meteorological variables that are in many cases related to precipitation. Besides, because precipitation is also associated with cloudiness, in certain cases precipitation may lead to less evaporation due to the reduction of solar radiation. In addition, vegetation cover controls evaporation and its changes may be also related to precipitation and its seasonal and interannual variability. Annual storage, the water accumulated in the different parts of the basin, including human-managed dams is also a function of annual precipitation. All these relationships between precipitation and other processes do not allow inferring the attribution of river-flow changes in long-term periods through a simple hydrological balance based only on precipitation and discharge data, because the sources of the evaporation change would not be identified.

Considering the many and complex ways that precipitation enters in Equation (1), a general approximation can be written as

$$
F_{\mathrm{i}}=f\left(P_{\mathrm{i}}\right)+O_{\mathrm{i}}
$$

where $F$ stands for the contribution of the basin to the river flow resulting from runoff, $f(P)$ is a function of precipitation, $O$ stands for all the processes or part of the processes that are independent of precipitation and $i$ for the year.

Figure 3 shows the discharges or contributions of each basin to the river flow at its closing point as a function of total precipitation over the basin; linear adjustments are also shown. Fitting other models like second order, log, potential or exponential do not improve the explained variance and in general accounts for less variance than the linear model. Thus, the linear fitting was retained for the following steps:

$$
F_{\mathrm{i}}=a \times P_{\mathrm{i}}+b+\varepsilon_{\mathrm{i}}
$$

In Equation $4, P_{\mathrm{i}}$ accounts not only for the direct effect of precipitation by its excess over evaporation, storage and infiltration, but also for the part of these processes that are linearly dependent on it. The slope of the linear regression, $a$, describes the fraction of any possible change in precipitation that, including all processes related with it, generates changes in river flow. $\varepsilon_{i}$ accounts for all the processes or part of the processes that are linearly independent on precipitation and contribute to control the runoff. The intercept of the line is given by $b$. The parameter $a$ varies from 0.23 in the north to 0.9 in the south, reflecting the higher mean temperature, and in the case of the Paraguay River, the slower runoff that implies a higher potential evapotranspiration level and consequently a smaller fraction of the rainfall apportion to the rivers.

Table IV includes the parameters of the linear regression and the explained variance $\left(R^{2}\right)$. The poorest adjustment is for the Pantanal Basin, where the slow runoff may transfer precipitation water from one year to the next; the percentage of precipitation that reaches the river is the smallest, Table II, and consequently the variability of other factors may have large impact on the river flow. In addition, rainfall data is scarce and its mean annual estimates may include some errors. The best fittings are in the basins with rapid flows, namely those of the Iguazú and the Uruguay Rivers, in which discharge also has the largest percent of precipitation, Table II.

To examine the contribution of the rainfall-independent processes which contribute to runoff, $\varepsilon_{i}$, to the long-term trends of river flows, their time series for each basin are presented in Figure 4. $\varepsilon_{i}$ evolves differently in each basin. In the northern ones, it increases with time but not always 

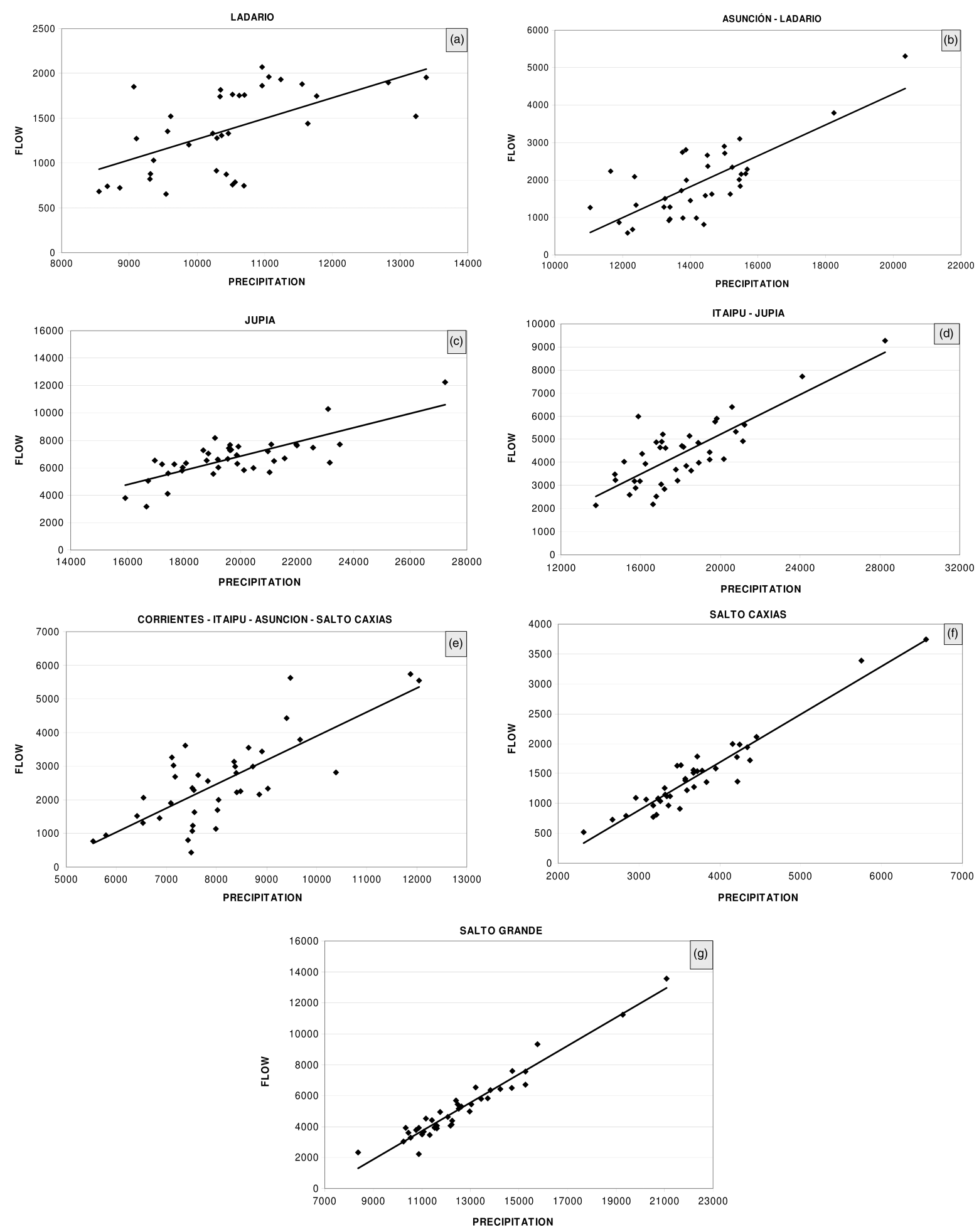

Figure 3. Annual river flows $\left(\mathrm{m}^{3} / \mathrm{s}\right)$ as a function of annual precipitation $\left(\mathrm{m}^{3} / \mathrm{s}\right)$. Linear adjustments are shown. (a) Ladario, (b) Asunción minus Ladario, (c) Jupiá, (d) Itaipú minus Jupiá, (e) Corrientes minus Itaipú minus Salto Caxias minus Asunción, (f) Salto Caxias and (g) Salto Grande.

during the same time period: in Jupiá (Figure 4(d)) augments during the 1960-1980 period, in the basin between Jupiá and Itaipú (Figure 4(e)) it starts in 1970 and in the two Paraguay Basins (Figure 4(b) and (c)) between 1970 and 1990. In Salto Caxias (Figure 4(f)), the trend in $\varepsilon_{i}$ only appears in the 1990s, while in the Uruguay River (Figure 4(a)) and in the Paraná section between Itaipú and Corrientes (Figure $4(\mathrm{~g})$ ) there are no trends at all. Except in these two basins, the rest of them present a common feature: positive $\varepsilon$ mean values in the second 20-year period of the four decades and a negative one in the first (Table IV). Figure 5 exemplifies this feature showing streamflows as a function of basin precipitation for the two 20-year periods in Jupia (Figure 5(b)) and Ladario (Figure 5(a)) showing that for a given precipitation, the river flows 
Table IV. Averaged variables over the 1960-1979, subscript 1, and 1980-1999 periods, subscript 2 (Equation (5)). Regression parameters of the linear adjustment of river flow as a function of precipitation as defined for Equation (4), and $R^{2}$ percent of explained variance. All values, except the dimensionless $a$ and $R^{2}$, are in $\mathrm{m}^{3} / \mathrm{s}$.

\begin{tabular}{|c|c|c|c|c|c|c|c|c|c|}
\hline Basin (Station) & $F_{1}$ & $F_{2}$ & $P_{1}$ & $P_{2}$ & $\varepsilon_{1}$ & $E_{2}$ & $A$ & $B$ & $R^{2}$ \\
\hline Pantanal (Ladario) & 1100 & 1660 & 10380 & 10460 & -240 & 290 & 0.231 & -1044 & 0.24 \\
\hline Middle Paraguay (Asunción-Ladario) & 1440 & 2440 & 13800 & 14720 & -290 & 340 & 0.413 & -3960 & 0.57 \\
\hline Northern Upper Paraná (Jupiá) & 6150 & 7260 & 19810 & 19730 & -560 & 600 & 0.519 & -3569 & 0.58 \\
\hline Southern Upper Paraná (Itaipú-Jupia) & 3600 & 5170 & 17550 & 18530 & -580 & 580 & 0.429 & -3367 & 0.64 \\
\hline Middle Paraná (Corrientes-Asunción-Itaipú-Salto Caxias) & 2280 & 2740 & 7620 & 8490 & 80 & -70 & 0.715 & -3253 & 0.58 \\
\hline Iguazú (Salto Caxias) & 1190 & 1690 & 3450 & 3930 & -60 & 60 & 0.801 & -1514 & 0.91 \\
\hline Uruguay (Salto Grande) & 4670 & 5790 & 11990 & 13310 & 90 & 0 & 0.918 & -6430 & 0.94 \\
\hline
\end{tabular}

Table V. Terms of Equation (5) as explained in the text, values in $\mathrm{m}^{3} / \mathrm{s}$. The percentage of the contribution to the change in river flows, $F_{2}-F_{1}$ is given in brackets.

\begin{tabular}{lccc}
\hline Basin (Station) & $F_{2}-F_{1}$ & $a \times\left(P_{2}-P_{1}\right)$ & $\varepsilon_{2}-\varepsilon_{1}$ \\
\hline Pantanal (Ladario) & 560 & $20(4)$ & $540(95)$ \\
Middle Paraguay (Asunción - Ladario) & 1000 & $380(38)$ & $630(62)$ \\
Northern Upper Paraná (Jupia) & 1120 & $-40(-4)$ & $1160(104)$ \\
Southern Upper Paraná (Itaipú-Jupia) & 1580 & $420(27)$ & $1160(73)$ \\
Middle Paraná (Corrientes-Asuncion-Itaipú-Salto Caxias) & 470 & $620(132)$ & $-150(-32)$ \\
Iguazú (Salto Caxias) & 500 & $380(76)$ & $120(24)$ \\
Uruguay (Salto Grande) & 1120 & $1210(108)$ & $-90(-8)$ \\
\end{tabular}

were consistently greater during the second period than in the first one. This feature is common to the other northern basins, and also to Salto Caxias, although in this case with fewer differences (not shown). In the case of the Uruguay Basin (Figure 5(c)) and in the Middle Paraná Basin (not shown), the river flow dependence on precipitation was almost the same in both periods.

From Table IV, it can be implied that mean river flows, in all basins, were larger in the second 20 -year period $\left(F_{2}\right)$ than in the first one $\left(F_{1}\right)$, consistent in most cases with the observed changes in precipitation.

Since changes in precipitation and $\varepsilon$ between the two 20-year periods have contributed to the augment of the river flows, to make this contribution explicit and quantitative, Equation (4) was averaged for each of the two 20-year periods and the first period was subtracted from the second, as follows:

$$
F_{2}-F_{1}=a \times\left(P_{2}-P_{1}\right)+\varepsilon_{2}-\varepsilon_{1}
$$

where subscripts 2 and 1 in $F, P$ and $\varepsilon$ denote averages over the 1980-1999 and 1960-1979 periods, respectively. $\varepsilon_{i}$ in Equation (4) also includes the variability of river flows with respect to precipitation for reasons inherent to the non-exact linear relationship, including part of water storage shift from one year to the next and possible errors. However, this shift tends to be compensated and fade out over long-term averages. Then, when considering 20-year periods, the second term on the right of Equation (5) is basically the contribution to river flow changes from the part of the evaporation that is not linearly dependent on precipitation, while the first term includes the evaporation changes that are statistically linearly associated to precipitation. Therefore, hereafter, $\varepsilon_{2}-\varepsilon_{1}$ will be called additional evaporation reduction for the sake of conciseness.

It is clear that the important changes in the discharges at Ladario and Jupia, closing points of the Pantanal and of the northern basin of the Paraná River respectively, cannot be explained by precipitation changes, as they respond entirely to the additional evaporation reduction (Table V). The sectors between Ladario and Asunción (Paraguay River) and between Jupiá and Itaipú in the southern Upper Paraná show positive changes in precipitation, but have only contributed 38 and $27 \%$ to the respective streamflows changes in these sections. The rest of the contribution to the change is accounted for by the reduction of the additional evaporation (Table V). In the Iguazú Basin, the discharge difference at Salto Caxias between the first and second 20-year periods was $500 \mathrm{~m}^{3} / \mathrm{s}$, meaning approximately a $40 \%$ increment. The dominant driver for this important change is the precipitation trend that tripled the contribution of the additional evaporation reduction. According to Table V, in the narrow strip of the Paraná Basin between Itaipú and the Iguazú outlet on one side and Corrientes on the other, there was a considerable change in the river flow; these changes were totally explained by the precipitation change that in a minor proportion were partially offset by an increase in the additional evaporation. The river flow change in the Uruguay Basin is completely explained by the precipitation change; this result is consistent with the conclusions obtained by Saurral et al. (2008) using a hydrological distributed model in the Uruguay River. As 

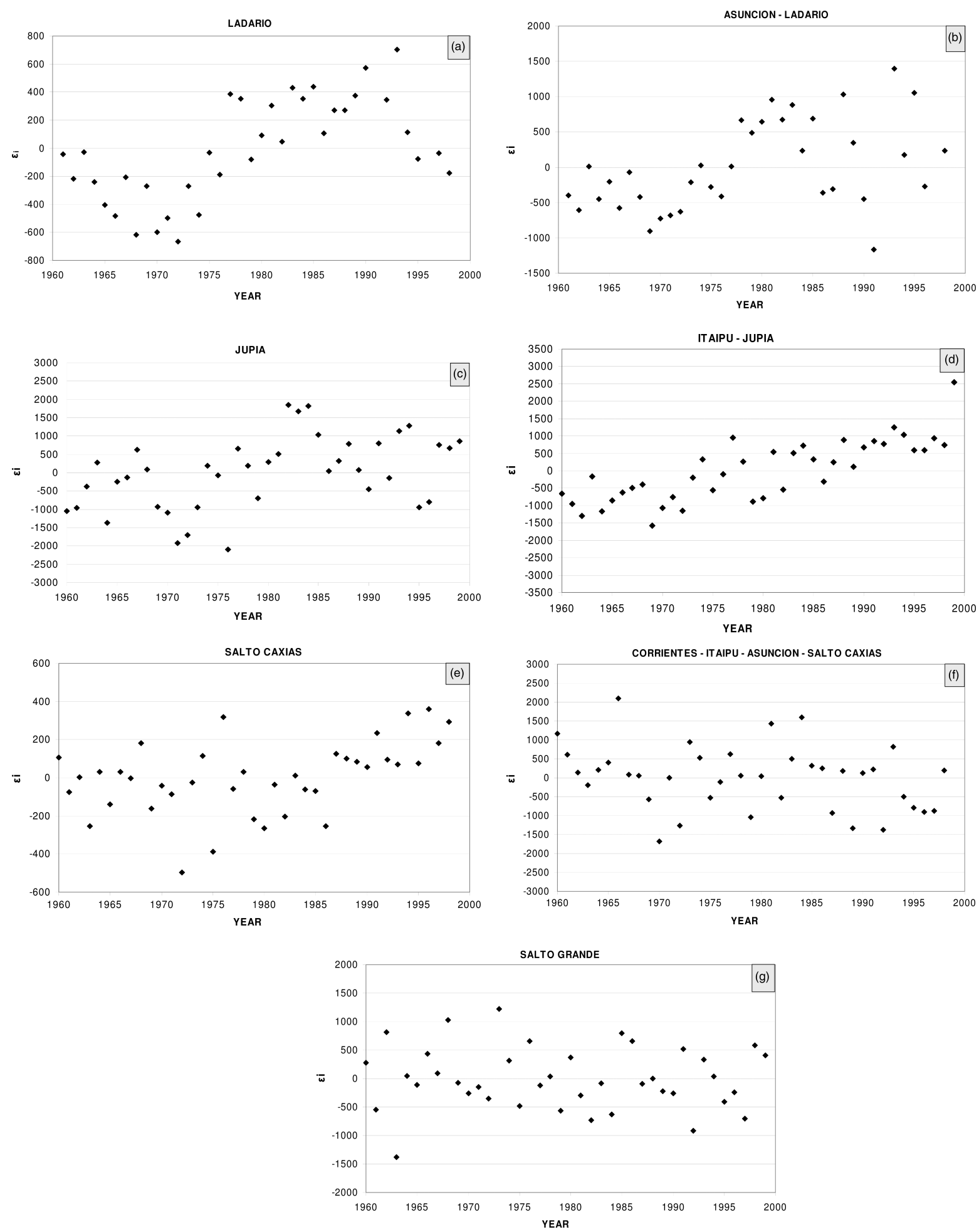

Figure 4. Annual difference between observed river flows and those estimated with a linear function of precipitation ( $\left.\mathrm{m}^{3} / \mathrm{s}\right)$. (a) Ladario, (b) Asunción minus Ladario, (c) Jupiá, (d) Itaipú minus Jupiá, (e) Salto Caxias, (f) Corrientes minus Itaipú minus Salto Caxias minus Asunción and (g) Salto Grande.

a synthesis, it can be concluded that the general pattern of change in the river flows responded to a decrease in the additional evaporation in the north of the Plata Basin and an increase in the precipitation in the south.

The additional evaporation may result from changes in meteorological conditions or ground conditions. Being an area where winds are relatively weak, humidity, temperature and radiation are the remaining meteorological variables to be considered. A difficulty frequently encountered in assessing evaporation is the absence of adequate observations of these meteorological variables; hence, some formulas were developed to assess potential evapotranspiration as a function of mean temperature, daily temperature range (DTR) or both plus a 

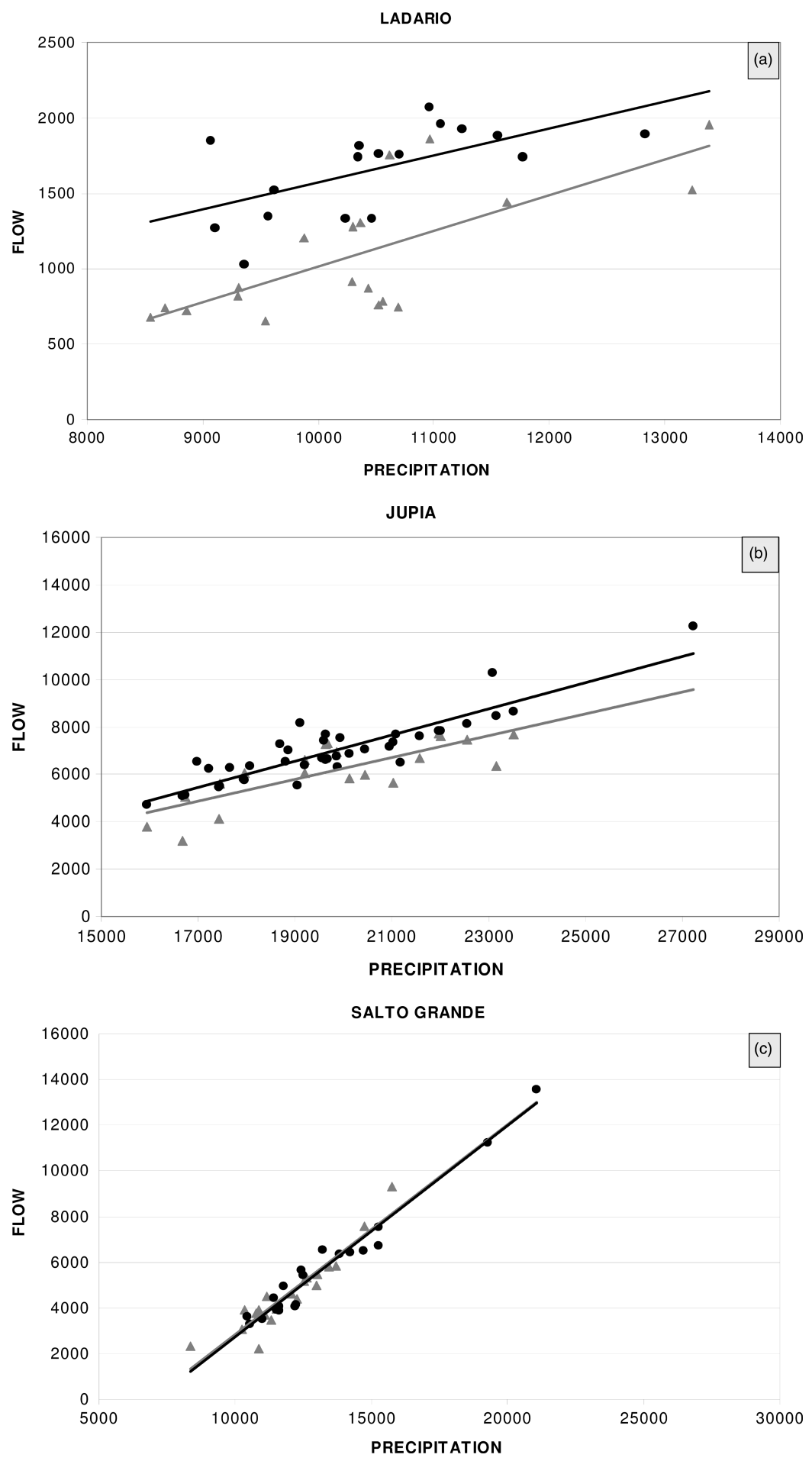

Figure 5. Annual river flows $\left(\mathrm{m}^{3} / \mathrm{s}\right)$ as function of annual precipitation $\left(\mathrm{m}^{3} / \mathrm{s}\right)$. Linear adjustments for the 1960-1979 period (grey triangle) and for 1980-1999 (black circle). (a) Ladario, (b) Jupiá and (c) Salto Grande.

geographical estimate of solar radiation (Thornthwaite, 1948; Blaney and Criddle, 1950; Turc, 1961; Hargreaves et al., 1985; Asanuma and Kamimera, 2004). These methods were tested by different authors and in general, give a good estimate of the annual mean evapotranspiration some of them with a $10 \%$ error (Xu and Singh, 1998).

In the five basins where additional evaporation accounts for a major or important fraction of the changes in the river flows, the differences between the mean temperatures averaged over each of the two 20 -year periods were very small. They range between -0.2 and $0.1^{\circ} \mathrm{C}$, with the exception of the Upper Paraná Basin, where the warming was $0.5^{\circ} \mathrm{C}$. DTR changes were always negative, ranging from -0.1 to -0.4 , but the trends were neither significant nor spatially homogeneous as reported by Vincent et al. (2005). Although, as a first-order approximation, these temperature changes seem small to make 
Table VI. Terms of Equations (8) and (9) as explained in the text, values in $\mathrm{m}^{3} / \mathrm{s}$. The percentage of the contribution to the change in the river flows, $F_{2}-F_{1}$ is given in brackets.

\begin{tabular}{lcccrr}
\hline Basin (Station) & $E_{2}-\varepsilon_{1}$ & $c \times\left(T_{2}-T_{1}\right)$ & $\delta_{2}-\delta_{1}$ & $e \times\left(\mathrm{DTR}_{2}-\mathrm{DTR}_{1}\right)$ & $\gamma_{2}-\gamma_{1}$ \\
\hline Pantanal (Ladario) & $540(95)$ & $10(2)$ & $530(93)$ & $160(29)$ & $380(66)$ \\
Middle Paraguay (Asunción-Ladario) & $630(62)$ & $60(6)$ & $570(56)$ & $170(17)$ & $470(45)$ \\
Northern Upper Paraná (Jupia) & $1160(104)$ & $490(44)$ & $670(60)$ & $300(27)$ & $860(77)$ \\
Southern Upper Paraná (Itaipú-Jupia) & $1160(73)$ & $60(3)$ & $1100(70)$ & $190(12)$ & $970(61)$ \\
Iguazú (Salto Caxias) & $120(24)$ & 0 & $120(24)$ & $20(4)$ & $100(20)$ \\
\hline
\end{tabular}

an important contribution to the river flow growth, this assumption was checked following the same procedure applied to precipitation. Thus, a linear approximation was assumed:

$$
\begin{aligned}
& \varepsilon_{\mathrm{i}}=c \times T_{\mathrm{i}}+d+\delta_{\mathrm{i}} \\
& \varepsilon_{\mathrm{i}}=e \times \mathrm{DTR}_{\mathrm{i}}+f+\gamma_{\mathrm{i}}
\end{aligned}
$$

This means a two-step linear regression, which is justified not only because it allows to pack all processes linearly related to precipitation in the first step but also because in this way the lower quality of temperature data does not contaminate the regression model described by Equation (4). After averaging Equations (6) and (7) for each of the two 20-year periods, the first period is subtracted from the second obtaining:

$$
\begin{aligned}
& \varepsilon_{2}-\varepsilon_{1}=c \times\left(T_{2}-T_{1}\right)+\left(\delta_{2}-\delta_{2}\right) \\
& \varepsilon_{2}-\varepsilon_{1}=e \times\left(\mathrm{DTR}_{2}-\mathrm{DTR}_{1}\right)+\left(\gamma_{2}-\gamma_{1}\right)
\end{aligned}
$$

Table VI presents each term of Equations (8) and (9) for upper and middle Paraguay, upper Paraná and Iguazú Basins. In general, the contribution of mean temperature changes to river flow changes is considerably lower than the contribution of nonlinear temperature processes represented by the second term on the right side of Equation (8). The exception is the northern Upper Paraná where this contribution reaches $44 \%$ of the flow change nonlinearly dependent on precipitation. The contribution to the river flow changes by the daily temperature range change is higher than in the case of temperature, but still considerably lower than that of the remaining term (Table VI).

The low explained variance $\left(R^{2}\right)$ of the linear regressions for each sub-basin indicates that $\varepsilon$ has a weak linear dependence on temperature and DTR. In the Pantanal, temperature only explains $2 \%$ of the additional evaporation and DTR 18\%; in the Middle Paraguay Basin, the variance explained by temperature and DTR are 0.03 and 0.11 , respectively. $R^{2}$ is somewhat higher in the case of temperature in the Northern Upper Paraná, 0.19, but it is still similar for DTR, 0.10; for the Middle Upper Paraná they are very low, 0.07 and 0.05 and for the Iguazú even lower, 0.02 in both cases.

The above is confirmed by Figures 6 and 7 which show the $\varepsilon$ values for the two 20-year periods as a function of temperature and DTR, respectively. It is clear that the main changes in $\varepsilon$ are time dependent, (Figure 4) and are reflected on the overall differences between the two periods with almost independence of the temperature variables, except from a weak dependence in some cases. Results shown in Figures 6 and 7 and Table VI imply that most of the contributions to river flow augment between the two 20-year periods that were not explained by rainfall changes were not caused by change in the other climate variables. Therefore, they should be attributed to the remaining process, i.e. changes in evapotranspiration related to the vegetation cover, which modify runoff and vary the time that water could be available for evaporation. Table VII summarizes the estimated values and ranges of the contribution of the drivers to the river flow increase.

\section{The ENSO phases and streamflow trends}

It is well known that anomalous precipitations in southeastern South America, a region that includes the Plata Basin, are related to ENSO phases, generally with more rainfall during El Niño and less during La Niña. It is also known that averaged flows during El Niño events were greater than those during La Niña episodes in the Uruguay River (Robertson and Mechoso, 1998), as well as in the Paraná River (Berri et al. 2002).

The number of months defining the positive and negative phases of ENSO was higher (lower) for El Niño (La Niña) during the 1980-1999 period than during 1960-1979, namely 87 (49) versus 72 (61). Thus, El Niño months became more frequent during the second 20-year period at the expense of La Niña months. Consequently, the number of months of the Neutral phase practically did not change, being 107 months in the first 20-year period and 104 in the second, which represents about $45 \%$ of the total months in each case.

To assess the streamflow changes originated by rainfall trends caused by ENSO changes, precipitation was averaged over each basin considering separately El Niño, La Niña and Neutral phases. Because of the longer (shorter) period of the El Niño (La Niña) phase during 1980-1999, more (less) precipitation should be expected in this period than in 1960-1979 as indeed was observed (Table VIII). In addition to the change in the number of months of each of this two ENSO phases, changes in the mean monthly rainfall could also have contributed to their different precipitation in each period. But, whatever the cause, this 

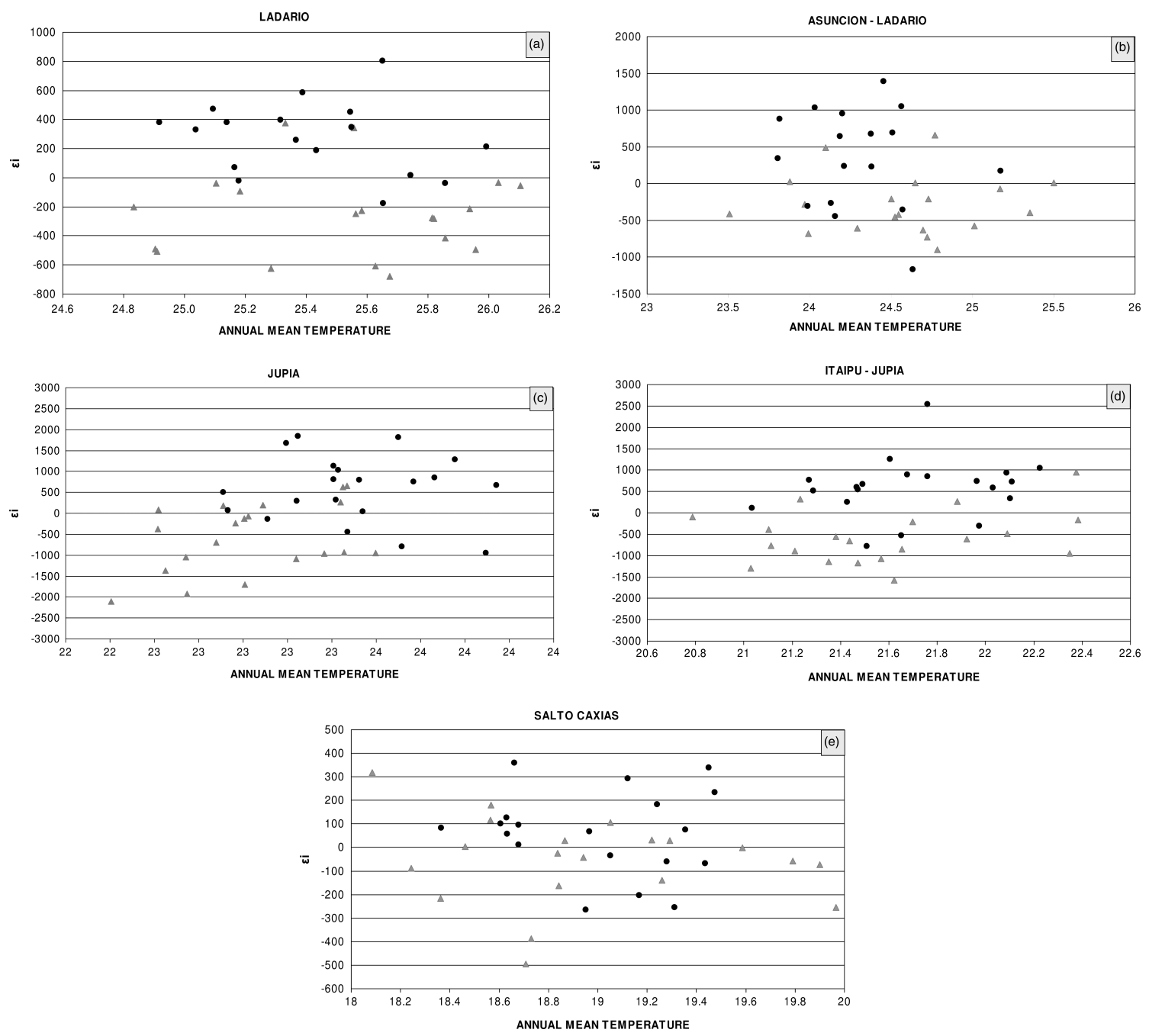

Figure 6. Difference $(\varepsilon)$ between observed annual river flows and estimated from a linear function of annual precipitation $\left(\mathrm{m}^{3} / \mathrm{s}\right)$ as a function of annual mean temperature $\left({ }^{\circ} \mathrm{C}\right.$ ) for the periods 1960-1979 (grey triangle) and 1980-1999 (black circle). (a) Ladario, (b) Asunción minus Ladario, (c) Jupiá, (d) Itaipú minus Jupiá, (e) Salto Caxias.

opposed behaviour tended to compensate the precipitation changes of these two ENSO phases as is seen in Table VIII (column 3). Since this was, at least partially, due to greater number of months of El Niño phase at the expense of the La Niña phase, it makes more sense to discuss the added contribution of both.

The incidence of precipitation changes on the respective river flow changes during the last four decades of the past century varied depending on the basin (Table V). The effect was negligible in the Pantanal and in the northern Upper Paraná River, it had a minor impact in the next downstream river sectors, i.e. the Middle Paraguay and southern Upper Paraná Rivers, it was the most important factor in the Iguazú River and the almost exclusive cause in the Middle Paraná and Uruguay Rivers. Since precipitation changes were not relevant in the Pantanal and in the northern Upper Paraná Basin, the impact of the ENSO phases in these basins is not discussed.

Except for the Middle Paraguay Basin, the added contribution of El Niño and La Niña phases to the precipitation changes between the two 20 -year periods account for less than $50 \%$ of the total change (Table VIII). Therefore, their added contributions to these changes are smaller than that of the Neutral phase even though the number of months of this phase was only about $45 \%$ in both periods. Hence, the increase in precipitation was not dominated by the changes in El Niño and La Niña phases. Furthermore, according to the values depicted in Table II, these added changes range only between 2 and $5 \%$ of the basin precipitation. Thus, it cannot be ruled out that the precipitation growth during the last four decades of the past century responded to other regional forcings, like increasing water vapour content in the atmosphere and/or nearby Atlantic sea-surface temperature changes.

These results reflect the pattern shown by Barros et al. (2008) where precipitation trends during El Niño phase dominate the contribution to the total precipitation trends only in a band running from northwestern Argentina to Paraguay, while in central Argentina and Uruguay, the main contribution to the positive precipitation trends comes from the Neutral phase. There is only one basin 

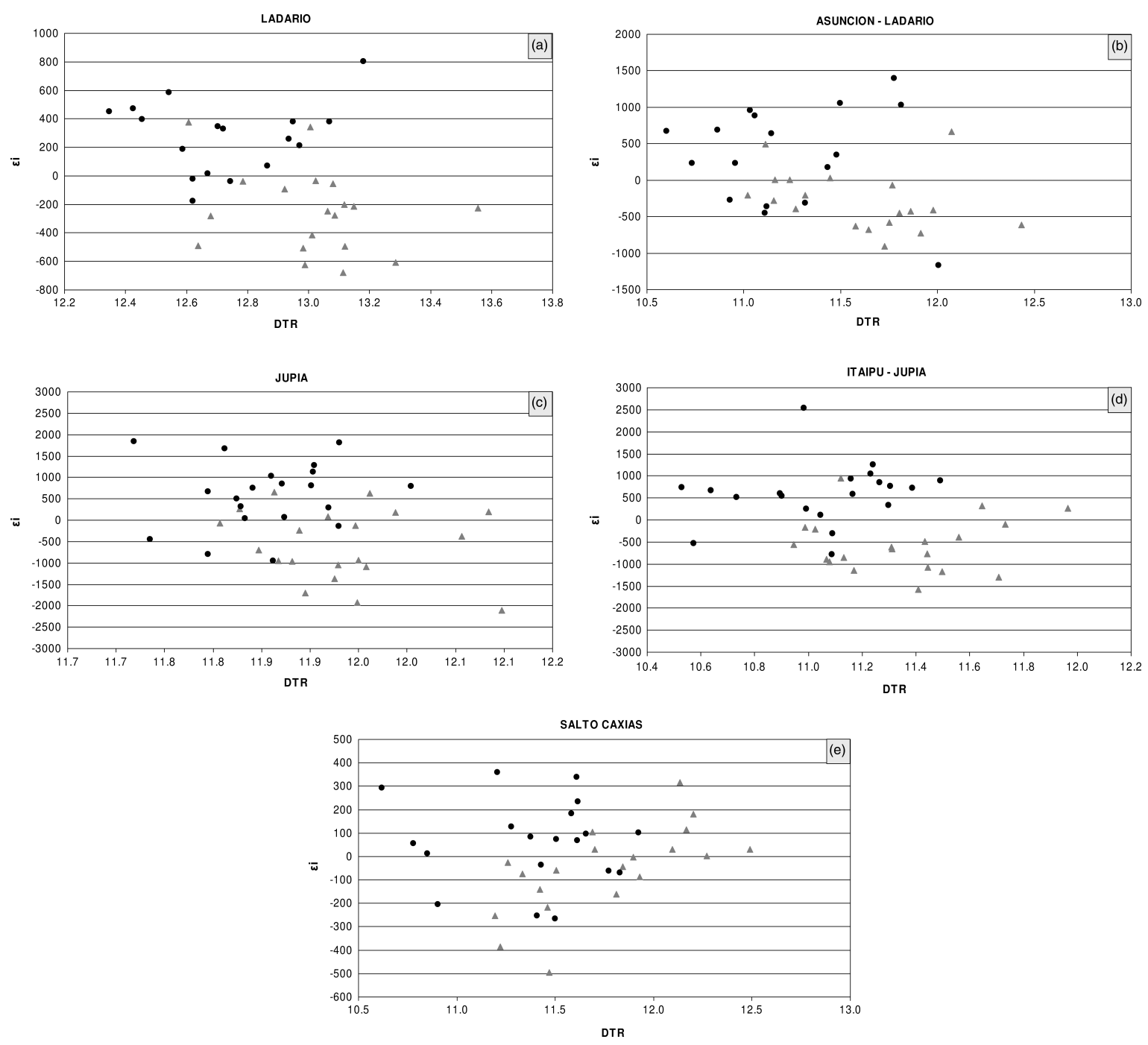

Figure 7. As Figure 6, but for mean annual daily temperature range.

Table VII. Estimated contribution (\%) to the river flow growth from 1960-1979 to 1980-1999.

\begin{tabular}{lccc}
\hline Basin (Station) & $\begin{array}{c}\text { Precipitation } \\
\text { related }\end{array}$ & $\begin{array}{c}\text { Other climate } \\
\text { variables }\end{array}$ & $\begin{array}{c}\text { Land } \\
\text { use }\end{array}$ \\
\hline Pantanal (Ladario) & 5 & $6-17$ & $43-56$ \\
Middle Paraguay (Asunción-Ladario) & 38 & $27-44$ & $69-77$ \\
Northern Upper Paraná (Jupia) & -4 & $27-44$ & $60-67$ \\
Southern Upper Paraná (Itaipú-Jupia) & 27 & $3-12$ & $61-70$ \\
Middle Paraná (Corrientes-Asunción-Itaipú-Salto Caxias) & $>100$ & $0-4$ & $<0$ \\
Iguazú (Salto Caxias) & 76 & $<0-24$ \\
Uruguay (Salto Grande) & $>100$ & $<0$ \\
\hline
\end{tabular}

where the precipitation increase during $\mathrm{El} \mathrm{Niño}$ and La Niña phases was greater than during the Neutral phase, i.e. in the Middle Paraguay Basin. However, its impact on the river flow change, according to Table VIII, Equation (5) and the value of $a$ (Table IV), was $230 \mathrm{~m}^{3} / \mathrm{s}$, which was merely $23 \%$ of the streamflow increment. In the rest of the Plata Basin, the precipitation trends associated with ENSO changes were not important in the streamflow changes of the last four decades of the 20th century.

\section{Concluding remarks}

The great enhancement of river flows in the Plata Basin during the last four decades of the 20th century was driven by three factors: a positive trend in precipitation over most of the basin, a negative evaporation trend that has a land use change footprint and a minor contribution from changes of other climate variables. As seen in Table VII, the relative contribution of these drivers varies throughout the basins. 
Table VIII. Difference of the integrated precipitation ( $\left.\mathrm{m}^{3} / \mathrm{s}\right)$ for the indicated basins from 1960-1979 to 1980-1999 for El Niño and La Niña phases and precipitation change rate of El Niño plus La Niña with respect to the total precipitation change.

\begin{tabular}{|c|c|c|c|c|}
\hline Basin (Station) & Niño & Niña & Niño + Niña & $\operatorname{Rate}(\%)$ \\
\hline Middle Paraguay (Asunción-Ladario) & 1320 & -760 & 560 & 66 \\
\hline Southern Upper Paraná (Itaipú-Jupia) & 1490 & -1080 & 410 & 40 \\
\hline Middle Paraná (Corrientes-Asuncion-Itaipú-Salto Caxias) & 770 & -390 & 380 & 45 \\
\hline Iguazú (Salto Caxias) & 360 & -190 & 170 & 35 \\
\hline Uruguay (Salto Grande) & 1162 & -581 & 581 & 45 \\
\hline
\end{tabular}

In the northern part of the Upper Paraná Basin, land use change including deforestation was the main driver that compensates and overweighs the negative rainfall trend, but it is likely that changes in climate variables, other than precipitation, played a complementary role. This result is consistent with the deforestation process (Volpi, 2008) during the last decades of the past century that led to less evapotranspiration as pastures and crops replaced natural vegetation. In the southern Upper Paraná Basin, land use change was also the dominant driver in the river flow increase, but in this case, the positive precipitation trend also contributed although in minor proportion. In this sense, this basin presented an intermediate behaviour between the northern part of the Upper Paraná and southernmost basins where rainfall trends were the dominant driver in the river flow enhancement. The attribution to land use change in the southern Upper Paraná Basin is consistent with the substitution of sugarcane and coffee trees for soybean that took place in Brazil (Tucci, 2003) and the deforestation in eastern Paraguay (Coronel et al., 2006).

In the Pantanal, where poor data availability is an important source of uncertainty, it seems that the dominant driver was also land use change, although perhaps with some contribution from changes in climate variables, other than precipitation. In fact, this region underwent a rapid transformation from a natural state to large-scale cattle raising. In the Middle Paraguay Basin, both land use change and a positive precipitation trend contributed to the river flow growth.

In the southernmost basins here considered, the Middle Paraná and Uruguay Basins, changes in the river flow were caused by precipitation trends with an insignificant contribution from land use change. In the case of the Iguazú Basin, there was an intermediate situation with a major contribution from the rainfall trend and to a lesser degree from land use change.

The change of the PDO to a positive phase that took place in the mid 1970s was accompanied by more frequent and intense El Niño events. However, in the southern Upper Paraná, Middle Paraná, Uruguay and Iguazú Basins, where rainfall trends contributed appreciably to the river flow growth, precipitation changes caused by El Niño and La Niña phases were not higher than those produced by the Neutral phase. The Middle Paraguay was the only basin where the impact of El Niño and La Niña phases on precipitation was important, resulting in a considerable contribution to the river flow growth.
In the southern basins, Middle Paraná, Iguazú and middle Uruguay, the relative importance of trends during ENSO phases was less significant, due to the incidence of other forcing processes. One of them could be the southern shift of the South Atlantic High's western border, likely related to climate change (Di Luca et al., 2006), that brought about higher summer rainfall over these basins (Barros et al., 2008).

These results have implications for the assessment of near future streamflows. On the one hand, it can be argued that the fraction of river flow changes owed to land use change may not vary substantially in the future, because there is little room left for great changes. On the other, in the basins where precipitation played a dominant role in the river flow growth, except in the Middle Paraguay Basin, changes related to ENSO interdecadal variability were not the main cause of rainfall trends, and therefore this interdecadal variability would not be a source of major changes.

Evaporation changes were only assessed indirectly through temperature, precipitation and streamflows due to the lack of other meteorological data. This is a source of uncertainty, particularly in regions where temperature observations were scarce. The use of hydrological models is an alternative and important approach to the issues addressed here. They have obvious advantages, but also serious limitations given the scarcity of data in large areas of the Plata Basin. Thus, the use of complementary approaches like the one developed here helps to increase confidence in results obtained from models. This is the case of the Uruguay River, where Saurral et al. (2008) using a distributed model arrived to the same conclusions as in this article.

\section{Acknowledgements}

The research leading to these results has received funding from the European Community's Seventh Framework Programme (FP7/2007-2013) under Grant Agreement $N^{\circ}$ 212492; UBACYT grant X033.

\section{References}

Aceituno P. 1988. On the functioning of the Southern Oscillation in the South American sector. Part I: surface climate. Monthly Weather Review 116: 505-524.

Asanuma J, Kamimera H. 2004. Long-term trends of the Pan Evaporation as an index of the global hydrological change. Symposium on Water Resource and Its Variability in Asia in the 21 st Century. Epochal, Tsukuba. Japan. 
Barros V, Castañeda E, Doyle M. 2000. Recent precipitation trends in southern South America to the east of the Andes: an indication of a mode of climatic variability. In Southern Hemisphere Paleo and Neoclimates Key - Sites, Methods, Data and Models, Springer: Berlin.

Barros V, Doyle M, Camilloni I. 2008. Precipitation trends in southeastern South America: relationship with ENSO phases and with low-level circulation. Theoretical and Applied Climatology 93: $19-33$.

Blaney HF, Criddle WD. 1950. Determining water requirements in irrigated areas from climatological and irrigation data. USDA Soil Conservation Service Tech., Paper No. 96, pp. 48.

Berbery EH, Barros V. 2002. The hydrologic cycle of the La Plata basin in South America. Journal of Hydrometeorology 3: 630-645.

Berri GJ, Ghietto MA, García NO. 2002. The influence of ENSO in the flows of the Upper Paraná River of South America over the past 100 years. Journal of Hydrometeorology 3: 57-65.

Bertoni JC, Maza JA, Paoli CU. 2003. Inundaciones y drenaje urbano en la Argentina (Urban floods and drainage in Argentina). Inundaçoẽs Urbanas na América do Sul (Urban Floods in South America), Tucci CEM, Bertoni JC (eds). Brazilian Water Resources Association: Porto Alegre, Brazil.

Castañeda ME, Barros V. 1994. Las tendencias de la precipitación en el Cono sur de América al Este de los Andes (Precipitation trends in the south cone of South America east of the Andes). Meteorológica 19: $23-32$.

Collischonn W, Tucci CEM, Clarke RT. 2001. Further evidence of changes in the hydrological regime of the River Paraguay: part of a wider phenomenon of climate change? Journal of Hydrology $\mathbf{2 4 5}$ : 218-238.

Coronel G, Menéndez A, Chamorro L. 2006. Fisiografía e hidrología de la Cuenca del Plata (Physiography and hydrology of La Plata basin). In El Cambio Climático en la Cuenca del Plata, Barros V, Clarke R, Silva Dias P (eds). CIMA-CONICET: Buenos Aires; 81-92.

Cressie NC. 1991. Statistics for Spatial Data, John Wiley and Sons: New York.

Di Luca A, Camilloni I, Barros V. 2006. Sea-level pressure patterns in South America and the adjacent oceans in the IPCC AR4 models. In 8th International Conference on Southern Hemisphere Meteorology and Oceanography. AMS. 235-244.

García NO, Vargas W. 1997. The temporal climatic variability in the Rio de la Plata basin displayed by river discharges. Climate Change 102: 929-945.

Genta JL, Perez-Iribarren G, Mechoso CR. 1998. A recent increasing trend in the streamflow of rivers in southeastern South America. Journal of Climate 11: 2858-2862.

Grimm AM, Barros VR, Doyle ME. 2000. Climate variability in southern South America associated with El Niño and La Niña events. Journal of Climate 13: 35-58.

Hamilton SK. 1999. Potential effects of a major navigation project (Paraguay-Paraná Hidrovía) on inundation in the Pantanal floodplains. Regulated Rivers: Research and Management 15: 289-299.

Haylock MR, Peterson TC, Alves LM, Ambrizzi T, Anunciação YMT, Baez J, Barros VR, Berlato MA, Bidegain M, Coronel G, Corradi V, Garcia VJ, Grimm AM, Karoly D, Marengo JA, Marino MB, Moncunill DF, Nechet D, Quintana J, Rebello E, Rusticucci M, Santos JL, Trebejo I, Vincent LA. 2006. Trends in total and extreme South American rainfall in 1960-2000 and links with sea surface temperature. Journal of Climate 19: 1490-1512.

Hargreaves GH, Samani ZA. 1985. Reference crop evapotranspiration from temperature. Applied Engineering in Agriculture 1(2): 96-99.

Hidroservice-Louis Berger-EIH. 1996. Estudios de Factibilidad Técnica y Económica de Obras de Ingeniería a Corto, Mediano y Largo Plazo Hidrovía de los Ríos Paraguay y Paraná (Technical and economic feasibility study for the short, medium and long term engineering. Waterway of the Paraná-Paraguay rivers). Digital Report for Intergovernmental Committee of the Waterway of the Paraná-Paraguay Rivers, Buenos Aires.
Krüger C, Kaviski E, Müller I. 1998. Análise de estacionariedade de séries hidrológicas na bacia incremental de Itaipu. (Analysis of the stationarity of hydrological series in the incremental basin of Itaipú). Revista Brasileira de Recursos Hídricos 3(4): 51-71.

Mantua NJ, Hare SR, Zhang Y, Wallace JM, Francis RC. 1997. A Pacific interdecadal climate oscillation with impacts on salmon production. Bulletin of the American Meteorological Society $\mathbf{7 8}$ : 1069-1079.

Matsuura K, Willmott CJ. 2009. Terrestrial Air Temperature: 19002008 Gridded Monthly Time Series, Version 2.01. Department of Geography, University of Delaware. Available from http://climate. geog.udel.edu/ climate/html_pages/archive.html. [accessed November 2009].

Rao VB, Hada K. 1990. Characteristics of rainfall over Brazil: annual variations and connections with the Southern Oscillation. Theoretical and Applied Climatology 42: 81-91.

Ropelewski CH, Halpert MS. 1987. Global and regional scale precipitation patterns associated with the El Niño/Southern Oscillation. Monthly Weather Review 115: 1606-1626.

Robertson AW, Mechoso CR. 1998. Interannual and decadal cycles in river flows of southeastern South America. Journal of Climate 11: 2570-2581.

Sahin MJ, Hall MJ. 1996. The effects of afforestation and deforestation on water yields. Journal of Hydrology 178: 293-309.

Saurral RI, Barros VR, Lettenmaier DP. 2008. Land use impact on the Uruguay River discharge. Geophysical Research Letters 35: L12401, DOI: 10.1029/2008GL033707.

Thornthwaite CW. 1948. An approach toward a rational classification of climate. Geographical Review 38: 55-94.

Trenberth KE. 1997. The definition of El Niño. Bulletin of the American Meteorological Society 78: 2271-2777.

Tucci CEM. 2003. Variabilidade climática e o uso do solo na bacia brasileira do Prata (Climate variability and land use in the Brazilian Plata basin). In Clima e Recursos Hídricos no Brasil (Climate and Water Resources in Brazil), ABRH, 9. Tucci CEM, Braga BPF (eds). Associacion Brasilera de Recursos Hidricos: Porto Alegre, Brazil, pp $163-242$.

Turc L. 1961. Estimation of irrigation water requirements, potential evapotranspiration: a simple climatic formula evolved up to date. Annales Agronomique 12: 13-49.

Vincent LA, Peterson TC, Barros VR, Marino MB, Rusticucci M, Carrasco G, Ramirez E, Alves LM, Ambrizzi T, Berlato MA, Grimm AM, Marengo JA, Molion L, Moncunill DF, Rebello E, Anunciação YMT, Quintana J, Santos JL, Baez J, Coronel G, Garcia J, Trebejo I, Bidegain M, Haylock MR, Karoly D. 2005. Observed trends in indices of daily temperature extremes in South America 1960-2000. Journal of Climate 18: 5011-5023.

Volpi G. 2008. Brazil case study. In Themba Report Contribution to the Gallagher Report (Report Authors Jeremy Woods and Mairi Black) UK. Available from http://www.renewablefuelsagency.gov.uk/sites/ renewablefuelsagency.gov.uk/files_documents/Themba_Local_land_ use_change_impacts_and_opportunities.pdf. [accessed September 2010].

Vose RS, Schmoyer RL, Steurer PM, Peterson TC, Heim R, Karl TR, Eischeid J. 1992. The Global Historical Climatology Network : Longterm MonthlyTemperature, Precipitation, SeaLevel Pressure, and Station Pressure Data, ORNL/CDIAC-53, NDP-041. Carbon Dioxide Information Analysis Center, Oak Ridge National Laboratory: Oak Ridge.

Willmott CJ, Matsuura K. 2001. Terrestrial air temperature and precipitation monthly and annual time series (1950-1999) Version 1.02. (http://climate.geog.udel.edu/ climate) [accessed November 2009].

Xu CY, Singh VP. 1998. Dependence of evaporation on meteorological variables at different time-scales and intercomparison of estimation methods. Hydrological Processes 12: 429-442, DOI: 10.1002/(SICI)1099-1085(19980315)12:3<429::AID-HYP581 $>3.0 . \mathrm{CO} ; 2-\mathrm{A}$.

Zhang Y, Wallace JM, Battisti D. 1997. ENSO-like interdecadal variability: 1900-1993. Journal of Climate 10: 1004-1020. 